\title{
Manajemen Logistik Dalam Menunjang Kegiatan Operasi Pencarian dan Pertolongan Pada Kantor Search And Rescue (SAR) Kelas A Biak
}

\author{
Krismiyati \\ Institut Ilmu Sosial dan Ilmu Politik Yapis Biak
}

\begin{abstract}
ABSTRAK
Penelitian ini dilakukan di Kantor SAR Kelas A Biak dengan tujuan untuk mengetahui bagaimana fungsi manajemen logistik dalam menunjang kegiatan operasi pencarian dan pertolongan pada kantor Search And Rescue (SAR) kelas A Biak. Metode yang digunakan dalam penelitikan ini adalah penelitian kualitatif dengan menggunakan analisis deskriptif kualitatif dan interpretatif dimana penelitian dilakukan sejak pengumpulan data dimulai. Dengan jumlah 10 informan. Dimana informan yang terpilih mempunyai kriteria permasalahan. Hasil penelitian menunjukan bahwa, penerapan manajemen logistik sudah berjalan dengan baik, manajemen logistik yang baik sangat diperlukan untuk menunjang kegiatan operasi pencarian dan pertolongan. Pengelolaan logistik yang sesuai dengan standart operasional prosedur/prosedur kerja yang berlaku akan mempermudah setiap aktifitas operasional yang akan diklakukan. Upaya-upaya peningkatan manajemen logistik masih perlu dilakukan demi terciptanya manajemen yang handal, efektif dan efisien dalam menunjang setiap kegiatan operasi pencarian dan pertolongan di Kantor Search and Rescue (SAR) Kelas A Biak.
\end{abstract}

Kata Kunci: SAR, Manajemen Logistik

\begin{abstract}
This research was conducted in the Office of Class A Biak SAR in order to know how the logistics management functions in supporting the search and rescue operation activities in the AA Search and Rescue (SAR) office Biak. The method used in this research is qualitative research using qualitative and interpretative descriptive analysis where the research has been conducted since the data collection started. With 10 informants. Where the selected informant has the criteria of the problem. The results show that, the implementation of logistics management is running well, good logistics management is needed to support the search and rescue operation activities. Logistics management in accordance with standard operating procedures / working procedures that apply will facilitate any operational activities to be treated. Efforts to improve logistics management still need to be done in order to create a reliable management, effective and efficient in supporting every search and rescue operation activities in the Office of Search and Rescue (SAR) Class A Biak.
\end{abstract}

Keywords: SAR, Logistics Management

\section{PENDAHULUAN}

Indonesia merupakan negara kepulauan terbesar di dunia yang memiliki sekitar 17.500 (tujuh belas ribu lima ratus) pulau dengan total luas wilayah kurang lebih 8 (delapan) juta kilometer persegi (Iskandar \& Erdelen, 2006). Seluas 1,8 (satu koma delapan) juta kilometer persegi dari wilayah indonesia tersebut dikelilingi wilayah laut teritorial dan 6,1 (enam koma satu) juta kilometer persegi merupakan jalur ekonomi eksklusif. Posisi wilayah yang strategis 
menjadikan Indonesia sebagai jalur perlintasan transportasi dunia dengan berbagai moda transportasi melalui wilayah indonesia untuk mencapai pulau, negara, atau bahkan benua lain. Posisi yang strategis tersebut berakibat pada mobilitas yang semakin tinggi sehingga kemungkinan terjadinya kecelakaan semakin meningkat (Anggarasena, 2010; Petrus, 2010; Supriyono, 2010).

Dalam menangani kecelakaan, setiap negara pada dasarnya memiliki kewajiban yang ditentukan dalam hukum nasional dan internasional. Pelaksanaan tersebut mutlak dilakukan demi terpenuhinya hak warga negara, melindungi dari berbagai macam ancaman bahaya, dan mempublikasikan hak-hak warga negaranya secara transparan. Hal itu berarti, Negara Kesatuan Republik Indonesia bertanggung jawab melindungi segenap bangsa dan seluruh tumpah darah indonesia dengan tujuan untuk memberikan perlindungan terhadap hidup dan kehidupannya sebagaimana diamanatkan dalam Undang-Undang dasar Negara Republik Indonesia Tahun 1945.

Salah satu pelaksanaan perlindungan warga negara tersebut adalah melakukan kegiatan pencarian dan pertolongan atau yang selama ini di kenal oleh masyarakat dengan search and rescue (SAR) (Munandar, 2008). Pencarian dan pertolongan pada hakikatnya merupakan kegiatan kemanusiaan dan merupakan kewajiban bagi setiap warga negara. Kegiatan tersebut meliputi segala upaya dan usaha pemberian pertolongan, penyelamatan, dan pengevakuasian jiwa manusia dan harta benda dari segala musibah, baik dalam kecelakaan, bencana maupun dalam kondisi - kondisi membahayakan manusia. Praktiknya, kegiatan pencarian dan pertolongan ini dilaksanakan oleh setiap negara di seluruh dunia, oleh sebab itu pengaturan mengenai pencarian dan pertolongan telah disepakati juga dalam konvensi internasional yang akan mengikat bagi negara - negara yang telah merativikasinya.

Berdasarkan ketentuan Organisasi Penerbangan Sipil Internasional (International Civil Aviation Organization / ICAO) dalam konvensi Chicago tahun 1944 pada pasal VI tentang International Standart and Recommended Practices Annex 12 "search and rescue " dan ketentuan Organisasi Pelayaran Internasional ( International Maritime Organization / IMO ) sesuai dengan konvensi Safety of Live at Sea ( SOLAS ) 1974, negara anggota organisasi tersebut wajib membentuk dan memiliki organisasi pencarian dan pertolongan yang mampu untuk menangani kecelakaan penerbangan dan pelayaran (Karamy, 2015). Apabila tidak dapat memberikan pelayanan di bidang pencarian dan pertolongan negara tersebut dikenai status black area yang akan berpengaruh terhadap aspek perekonomian, sosial politik, pertahanan, keamanan dan aspek lain, bahkan dapat dikenai sanksi berupa larangan terbang dan berlayar melintasi wilayah tersebut.

Berdasarkan Undang-Undang Republik Indonesia Nomor 29 tahun 2014 Tentang Pencarian dan Pertolongan, Badan Nasional Pencarian dan Pertolongan atau yang lazim disebut BASARNAS adalah lembaga nonkementrian yang menyelenggarakan urusan pemerintahan dibidang pencarian dan pertolongan. Dari batasan pengertian dan hakikat pencarian dan pertolongan diatas, jelas bahwa kegiatan pencarian dan pertolongan yang utama adalah pelaksanaan operasi pencarian serta pemberian pertolongan, penyelamatan dan evakuasi korban untuk mencegah atau mengurangi kefatalan dalam kecelakaan, kondisi yang membahayakan manusia dan bencana alam. Namun, pelaksanaan operasi tersebut hanya dapat berjalan efektif dan efisien apabila dilakukan secara cepat, tepat, aman, terpadu dan terkoordinasi. Untuk dapat 
melaksanakan pelayanan pencarian dan pertolongan dengan cepat, tepat, aman dan terpadu memerlukan komponen - komponen SAR yaitu: Organisasi SAR, Komunikasi SAR, Fasilitas/Logistik SAR, Pertolongan darurat, dan Dokumentasi SAR.

Kelima komponen SAR tersebut saling berkaitan dalam menunjang kegiatan operasi pencarian dan pertolongan sehingga apabila salah satu komponen tersebut tidak berfungsi dengan baik maka kegiatan operasi pencarian dan pertolongan tidak dapat berjalan dengan lancar. Komponen - komponen SAR tersebut menjadi faktor yang penting dalam keberhasilan pelaksanaan operasi SAR. Salah satu komponen SAR yang sangat penting dalam menunjang kegiatan operasi SAR adalah Logistik SAR.Logistik didefinisikan sebagai keseluruhan bahan, barang, alat dan sarana yang diperlukan dan digunakan oleh suatu organisasi dalam rangka pencapaian tujuan dan berbagai sasarannya (Siagian, 2003). Logistik adalah segala sesuatu atau benda yang berwujud dan dapat diperlakukan secara fisik, baik yang digunakan untuk menyelenggarakan kegiatan pokok maupun kegiatan penunjang (Irmawati \& PGDHS, 2015).

Manajemen Logistik merupakan kegiatan mengenai perencanaan dan penentuan kebutuhan, pengadaan, penyimpanan, penyaluran dan pemeliharaan serta penghapusan material atau barang barang. Spesifikasinya logistik memiliki hubungan erat dengan persediaan barang. Manajemen Logistik SAR adalah kegiatan pengadministrasian, pengecekan, penyimpanan dan pendistribusian sarana dan prasarana SAR sesuai dengan peraturan dan prosedur yang berlaku untuk mendukung kelancaran operasi dan latihan SAR.Peranan logistik SAR dalam mendukung keberhasilan operasi pencarian dan pertolongan sangat besar karena tugas logistik SAR dalam pelaksaaan operasi adalah mengadministrasi, menyimpan, pengecekan serta pendistribusian sarana dan prasarana, bahan makanan, dan bahan bakar guna menunjang pelaksanaan operasi pencarian dan pertolongan. Manajemen Logistik yang baik menjadi kunci utama dalam keberhasilan pendistribusian logistik SAR untuk menunjang kegiatan operasi pencarian dan pertolongan. Kantor SAR kelas A biak merupakan unit pelaksana teknis (UPT) dibidang pencarian dan pertolongan yang berada dibawah dan bertanggung jawab kepada Kepala Badan SAR Nasional (Basarnas). Kantor SAR kelas A Biak secaara teknis administratif dibina oleh Sekretaris Utama dan secara teknis fungsional dibina oleh Deputi Bidang Operasi SAR dan Deputi Bidang Potensi SAR. Kantor SAR kelas A biak mempunyai tugas melaksanakan siaga SAR, Pelatihan SAR, melaksanakan tindak awal dan operasi SAR serta Pengelolaan Sarana / Prasarana dan Peralatan SAR, oleh karna itu memiliki wewenang sebagai pengguna barang dan memiliki kewajiban untuk melaksanakan manajemen logistik sesuai prosedur dan peraturan yang berlaku.

Namun dalam pelaksanaan logistik SAR di Kantor SAR Kelas A Biak masih ditemukan kekurangan pada banyak hal, pengadministrasian logistik SAR sering kali masih dilaksanakan seadanya, belum tersedianya perlengkapan pendukung pengadministrasian seperti tempat penyimpanan file - file untuk barang keluar dan masuk logistik, tempat penyimpanan barang barang logistik sangat terbatas dan masih kurang memadai serta pendistribusian barang barang logistik masih banyak yang kurang sesuai dengan prosedur dan peraturan yang berlaku. Kurangnya kesadaran petugas logistik mengenai pentingnya pengecekan, perawatan, penyimpanan serta pendistribusian barang - barang logistik dengan benar juga menjadi salah 
satu kendala dalam pelaksanaan manajemen logistik SAR. Berbagai permasalahan tersebut akan menghambat kelancaran operasi pencarian dan pertolongan.

\section{METODE PENELITIAN}

Jenis penelitian ini menggunakan deskriptif kualitatif. Penelitian Lokasi tempat penulis melakukan penelitian, berlokasi di kantor Search And Rescue (SAR) Kelas A Biak. kualitatif adalah penelitian yang bermaksud untuk memahami fenomena tentang apa yang dialami oleh subyek peneliti misalnya perilaku, cara deskripsi dalam bentuk kata-kata dan bahasa, pada suatu konteks khusus yang alamiah dan dengan memanfaatkan berbagai metode ilmiah (Moleong, 2007). Penelitian kualitatif tidak menggunakan istilah populasi, tetapi menggunakan "social situation" atau situasi sosial yang terdiri dari tiga elemen yaitu : tempat (place), pelaku (actor), dan aktivitas (activity) yang berinteraksi secara sinergis. Pendekatan kualitatif ini diambil karena dalam penelitian ini sasaran atau obyek penelitian dibatasi agar data-data yang diambil dapat digali sebanyak mungkin serta agar dalam penelitian ini tidak dimungkinkan adanya pelebaran obyek penelitian.Penelitian kualitatif menggunakan metode kualitatif yaitu pengamatan, wawancara, atau penelaahan dokumen. Metode ini digunakan karena beberapa pertimbangan. Yang pertama, menyesuaikan metode kualitatif lebih mudah apabila berhadapan dengan kenyataan jamak. Kedua, metode ini menyajikan secara langsung hakikat hubungan antara peneliti dan responden. Ketiga, metode ini lebih peka dan lebih dapat menyesuaikan diri dengan banyak penajaman pengaruh bersama terhadap pola-pola nilai yang dihadapi (Moleong, 2007). Dari teori-teori diatas dapat ditarik kesimpulan bahwa penelitian deskriftif kualitatif menggunakan langkah-langkah penelitian dari fenomena yang dapat dijelaskan secara terperinci dan ilmiah. Pengamatan ilmiah yang dimaksudkan adalah pengamatan yang dimulai dari hal-hal $\mathrm{kecil} / \mathrm{sempit} \mathrm{ke} \mathrm{hal-hal} \mathrm{yang} \mathrm{lebih} \mathrm{besar/} \mathrm{luas.}$

\section{HASIL PENELITIAN DAN PEMBAHASAN}

Pelaksanaan Operasi Pencarian Dan Pertolongan (SAR) merupakan salah satu tugas utama Kantor SAR Kelas A Biak sebagai Unit Pelaksana Teknis dari Badan SAR Nasional. Sebagai organisasi yang bergerak dibidang kemanusiaan kantor SAR Biak dituntut untuk mampu melaksanakan tugas-tugasnya serta memberikan pelayanan yang terbaik bagi masyarakat, untuk meningkatkan pelayanan jasa Pencarian dan Pertolongan maka perlu diperhatikan setiap komponen-komponen SAR yang menjadi penunjang keberhasilan pada setiap pelaksanaan operasi pencarian dan pertolongan yaitu : Organisasi SAR, Komunikasi SAR, Fasilitas/Logistik SAR, Pertolongan darurat dan Dokumentasi SAR.Salah satu komponen yang sangat penting untuk menunjang keberhasilan Operasi Pencarian dan pertolongan adalah Logistik SAR, keberadaan logistik dalam pelaksanaan pencarian dan pertolongan adalah sebagai fasilitas pendukung, penyediaan kendaraan operasional, peralatan SAR, bahan bakar, bahan makanan, serta perlengkapan medis yang dibutuhkan selama operasi pencarian dan pertolongan. Mengingat begitu pentingnya logistik SAR maka perlu adanya manajemen yang efektif dan efisien demi tercapainnya tugas-tugas kemanusiaan dan peningkatan pelayanan bagi 
50| Jurnal Ilmiah Ilmu Administrasi Publik, Vol.7, No.1, 2017

masyarakat.Berdasarkan dengan manajemen logistik dalam menunjang pelaksanaan operasi pencarian dan pertolongan pada Kantor Search And Rescue (SAR) kelas A Biak, maka ada indikator-indikator yang penulis amati kemudian dituangkan dalam pembahasan ini.

\section{Pendidikan}

Setiap organisasi akan senantiasa berupaya untuk mencapai tujuan berorganisasi dengan efektif dan efisien, untuk mewujudkan itu semua perlu adanya peningkatan sumber daya manusia atau anggota dalam organisasi tersebut. Ini berarti bahwa sumber daya manusia yang ada dalam organisasi tersebut secara proporsional harus diberikan pendidikan yang sebaikbaiknya, karena salah satu pengembangan sumber daya pegawai adalah pendidikan. Siagian, (1991) menyatkan bahwa "pendidikan sebagai keseluruhan proses, teknik dan metode belajar mengajar dalam mengalihkan suatu pengetahuan dari seseorang kepada orang lain sesuai dengan standar yang telah ditetapkan sebelumnya".Pendidikan pegawai sangat perlu diperhatikan agar pelaksanaan tugas dan tujuan organisasi yang efektif dan efisien dapat tercapai, pada umumnya para pegawai mengharapkan agar mereka ditempatkan sesuai dengan jenis dan tingkat pendidikan yang diikutinya. Berdasarkan pernyataan diatas maka penempatan pegawai-pegawai kantor SAR Kelas A Biak yang sesuai dengan pendidikan yang telah diikutinya akan berdampak pada peningkatan kinerjanya.

\section{Pelatihan / Diklat}

Dengan adanya pelatihan sebagai bagian pengembangan pegawai, maka organisasi dapat meningkatkan hasil-hasil kerja atau kinerja pegawai. Menurut Ali (2009) bahwa : diklat aparatur mengarah pada upaya peningkatan sikap dan semangat pengabdian yang berorientasi pada kepentingan masyarakat, bangsa, negara dan tanah air. Manfaat dari penyelenggaraan program pelatihan atau diklat sangat berguna untuk meningkatkan ilmu dan keahlian pegawai kantor SAR Kelas A Biak, terlebih ilmu dan keahlian dalam bidang Pencarian dan Pertolongan yang berguna untuk mensukseskan misi pencarian dan pertolongan.

\section{Keterampilan}

Secara umum keterampilan dapat dibagi menjadi tiga bagian pokok menurut Katz (2009) yaitu "technical skill, conceptual skill and human skilll". Technical skill adalah kemampuan untuk menggunakan alat-alat, prosedur dan teknik suatu bidang khusus. Dalam melaksanakan tugasnya seorang pegawai SAR harus memiliki kemampuan teknis yang cukup. Keterampilan konseptual adalah kemampuan mental untuk mengkoordinasi dan memadukan semua kepentingan dan kegiatan organisasi. Kemampuan ini mendukung pegawaai untuk mampu memandang organisasi secara keseluruhan dan memahami masalah yang dihadapi. Dengan kemampuan ini, pegawai dapat melakukan perencanaan kerja dengan memperhitungkan kemampuan-kemamuan organisasi serta tujuan yang hendak dicapai.Manajemen logistik dalam menunjang kegitan operasi pencarian dan pertolongan bukanlah suatu hal yang mudah dilakukan karena didalamnya terdapat banyak kegiatan yang harus diselesaikan dan dikerjakan dengan teliti, efektif dan tentunya juga efisien. 
Krismiyati, Manajemen Logistik Dalam Menunjang Kegiatan Operasi Pencarian dan Pertolongan

Pada Kantor Search And Rescue (SAR) Kelas A Biak $\mid 51$

\section{Etos Kerja}

Etos kerja adalah sikap yang muncul atas kehendak dan kesadaran sendiri yang didasari oleh sistem orientasi nilai budaya terhadap kerja. Etos kerja mempunyai dasar nilai budaya, dari nilai budaya itulah yang membentuk etos kerja masing-maing pribadi pegawai. Etos kerja dapat diartikan sebagai konsep tentang kerja atau paradigma kerja yang diyakini oleh seseorang atau kelompok orang sebagai hal yang baik dan benar yang diwujudnyatakan melalui perilaku kerja mereka secara khas. Etos kerja adalah totalitas kepribadian dirinya serta caranya mengekspresikan, memandang, meyakini dan memberikan makna pada sesuatu, yang mendorong dirinya untuk bertindak dan meraih amal yang optimal sehingga pola hubungan antara manusia dengan dirinya dapat terjalin dengan baik. Apabiala etos kerja pada Kantor SAR Kelas A Biak berjalan dengan baik maka akan berpengaruh positif pada manajemen logistik dalam menunjang kegiatan operasi pencarian dan pertolongan.

\section{Iklim Kerja}

Iklim kerja atau suasana kerja dalam lingkungan pekerjaan sangat mempengaruhi kinerja pada Kantor SAR Kelas A Biak. Jika iklim kerja yang diciptakan baik, maka pegawai akan bekerja dengan maksimal serta memberikan pelayanan yang terbaik. Dan sebaliknya apabila suasana kerja kurang baik maka akan berakibat pada kurangnya hasil kinerja dan pelayanan yang tidak maksimal. Untuk itu iklim kerja pada Kantor SAR Kelas A Biak perlu dipelihara dengan baik oleh Seluruh pegawai serta para pimpinan demi terjaganya harmonitas dalam lingkungan kerja.

\section{Pengawasan}

Pengawasan merupankan salah satu fungsi dalam manajemen suatu organisasi. Yang memiliki arti suatu proses mengawasi dan mengevaluasi suatu kegiatan. Maksud dan tujuan dilakukan pengawasan yaitu mengetahui jalannya suatu pekerjaan apakah sudah berjalan lancar atau tidak, memperbaiki kesalahan yang mungkin dilakukan oleh pegawai dan mengupayakan pencegahan agar tidak terulang kembali kesalahan yang sama atau timbul kesalahan yang baru, mengetahui penggunaan anggaran yang telah ditetapkaan dalam perencanaan awal apakah sudah sesuai dengan yang direncanakan, mengetahui pelaksanaan kerja sesuai dengan program kerja serta mengatahui hasil pekerjaan dibandingkan dengan yang telah ditetapkan dalam perencanaan. Apabila pengawasan tidak dilaksanakan dengan baik serta sesuai dengan peraturan yang berlaku maka tujuan organisasi atau pelaksanaan tugas termasuk manajemen logistik dikhawatirkan akan terjadi penyimpangan-penyimpangan serta tidak dapat mencapai tujuan yang telah ditetapkan dengn maksimal. 
Perencanaan logistik dalam menunjang kegiatan operasi pencarian dan pertolongan pada Kantor Search And Rescue (SAR) Kelas A Biak.

Perencanaan logistik SAR adalah serangkaian kegiatan dalam menyusun, menyiapkan dan memperhitungkan barang-barang logistik yang akan digunakan untuk mendukung pelakasanaan operasi pencarian pertolongan. Perencanaan logistik SAR hendaknya tersusun rapi dan baik. Berikut kesimpulan hasil wawancara yang dilakukan oleh penliti kepada Bapak john Max Wenno Untuk informan selanjutnya bapak Mathius Amba Dari pernyataan-pernyataan Informan diatas, tujuh informan memberikan tanggapan/jawaban baik terhadap perencanaan logistik dalam menunjang pelaksanaan operasi pencarian dan pertolongan pada Kantor Search And Rescue (SAR) Kelas A Biak sedangkan tiga informan lainnya memberikan tanggapan perencanaan logistik masih kurang baik.

\section{Pengelolaan Logistik SAR pada Kantor Search And Rescue (SAR) Kelas A Biak.}

Pengelolaan logistik yang dimaksud adalah serangkaian aktivitas untuk melakukan penyimpanan, perawatan, dan juga pendistribusian logistik SAR secara baik dan sesuai prosedur yang berlaku, hal tersebut dilakukan guna menunjang aktivitas kegiatan operasi pencarian dan pertolongan maupun latihan-latihan SAR. Pengelolan logistik adalah tugas dan tanggung jawab petugas logistik, meskipun demikian setiap pegawai kantor SAR biak juga wajib untuk ikut serta merawat serta dan menjaga logistik tersebut karena itu merupakan barang/aset/alat milik kantor SAR Biak.Menurut informan bapak John (wawancara pada tanggal 09 mei 2016) tentang pertanyaan "Bagaimana pengelolaan logistik pada kantor SAR Biak?" Berdasarkan jawabanjawaban dari informan yang peneliti wawancarai diatas lima informan memberikan tanggapan perlunya perbaikan/ peningkatan dalam hal pengelolaan logistik mulai dari penyimpanan, perawatan serta pendistribusiannya. Sedangkan lima informan lainnya memberikan tanggapan bahwa pengelolaan logistik sudah cukup baik.

\section{Pengadaan Logistik SAR Pada Kantor Search and Rescue (SAR) Biak.}

Pengadaan barang-barang logistik dimaksudkan sebagai usaha atau kegiatan untuk memenuhi kebutuhan operasional yang sebelumnya telah ditentukan dalam perencanaan logistik SAR. Dengan terpenuhinya kebutuhan-kebutuhan operasional dari pengadaan logistik, diharapkan dapat memaksimalkan tugas operasi pencarian dan pertolongan. Berikut ini adalah hasil wawancara dengan para informan mengenai pertanyaan "Apakah pengadaan logistik pada kantor SAR biak selama ini sudah sesuai dengan kebutuhan operasi SAR Dari penyataanperyataan ke-10 informan diatas dapat ditarik kesimpulan tujuh informan menyatakan pengadaan logistik sudah cukup baik dan sesuai dengan kebutuhan operasi SAR. Namun tiga informan yang lainnya memberikan tanggapan pengadaan logistik belum sesuai dengan kebutuhan dan perlu ditingkatkan untuk perbaikan.

Pengawasan terhadap pengelolaan logistik pada Kantor Search And Rescue (SAR) Kelas A Biak. 
Pelaksanaan pengawasan bertujuan untuk mengamati, mengontrol serta mengamankan keseluruhan pengelolaan logistik, dalam hal ini terdapat kegiatan-kegiatan pengendalian inventarisasi atau administrasi logistik dan pengendalian distribusi logistik. Apabila pengawasan dijalankan dengan baik maka pengelolaan logistik akan terkontrol dan berjalan dengan lancar.Setelah mengamati jawaban-jawaban dari informan dapat disimpulkan bahwa dari sepuluh informan yang diwawancarai pada tanggal 10 mei 2016 delapan diantarannya menyatakan pengawasan terhadap pengelolaan logistik sudah berjalan dengan baik. Sedangkan dua informan memberikan tanggapan bahwa pengawasan pengelolaan logistik kurang baik dan perlu peningkatan.

Manajemen Logistik merupakan kegiatan mengenai perencanaan dan penentuan kebutuhan, pengadaan, penyimpanan, penyaluran dan pemeliharaan serta penghapusan material atau barang-barang. Manajemen Logistik SAR adalah kegiatan pengadministrasian, pengecekan, penyimpanan dan pendistribusian sarana dan prasarana SAR sesuai dengan peraturan dan prosedur yang berlaku untuk mendukung kelancaran operasi dan latihan SAR. Penerapan manajemen logistik yang sesuai dengan SOP yang berlaku akan benar-benar bermanfaat untuk mendukung kegiatan operasi pencarian dan pertolongan. Dalam hal ini penulis melakukan penelitian dengan mengacu pada rumusan masalah fungsi manajemen logistik dalam menunjang kegiatan operasi pencarian dn pertolongan Pada Kantor Search and Rescue (SAR) Kelas A Biak.

Fungsi-fungsi manajemen logistik yang penulis maksud adalah Perencanaan, Pengelolaan (penyimpanan, perawatan dan pendistribusian logistik), Pengadaan dan Pengawasan Logistik. Berdasarkan hasil penelitian melalui Pengamatan, wawancara dan pengumpulan data-data yang relevan, pelaksanaan manajemen logistik di Kantor SAR kelas A Biak pada saat ini secara umum berjalan dengan baik, hal itu dibuktikan dari hasil wawancara dengan 10 informan kantor SAR Biak. Rata-tara tujuh dari sepuluh informan diantaranya memberikan pendapat/ tanggapan yang positif mengenai pertanyaan-pertanyaan yang penulis ajukan dalam wawancara. Sedangkan rata-rata tiga informan memberikan pendapat/tanggapan negatif atau kurang baik dalam hasil wawancara. Pendapat positif dan negatif yang dimaksud adalah : Pendapat positif yaitu, dalam hasil wawancara informan meyatakan bahwa manajemen logistik dikantor SAR kelas A Biak sudah berjalan dengan baik dan sesuai dengan prosedur mulai dari perencanaan, pengelolaan, pengadaan hingga pengawasaanya. Sedangkan pendapat negatif yaitu, informan menyatakan bahwa manajemen logistik dikantor SAR kelas A Biak masih kurang baik, dalam hal perencanaan, pengelolaan, pengadaan maupun pengawasannya. Jika dikaitkan dengan teoriteori, manajemen Logistik di kantor SAR Biak sudah mendekati teori-teori yang ada. Namun masih perlu ditingkatkan dan disempurnakan untuk mendapatkan hasil yang maksimal.

Masalah-masalah yang timbul dalam manajemen logistik bisa diselesaikan atau dipecahkan dengan cara meningkatkan fungsi pengawasan, pelaksanaan manajemen sesuai dengan prosedur kerja yang berlaku, meningkatkan SDM pada bidang manajemen logistik dan tentunya kesadaran pegawai kantor SAR Biak untuk bekerja penuh tanggung jawab dan profesional. Setiap masalah yang timbul dalam suatu organisasi dapat dijadikan bahan evaluasi dan kajian untuk membenahi kinerja organisasi tersebut. Demikian pula dengan Kantor SAR Kelas A Biak, kendala-kendala yang muncul dalam manajemen logistik ataupun dalam bidang lainnya akan dievaluasi dan dikaji untuk meningkatkan kualitas kerja pegawainnya, demi 
54| Jurnal Ilmiah Ilmu Administrasi Publik, Vol.7, No.1, 2017

tercapainya visi dan misi sebagai instansi pemerintah yang bertugas memberikan jasa pelayanan pencarian dan pertolongan.

\section{SIMPULAN}

Pengelolaan logistik yang sesuai dengan SOP yang barlaku akan memudahkan setiap aktifitas operasional yang akan dilakukan. Kemudian pengadaan logistik yang sesuai dengan kebutuhan akan memaksimalkan setiap pelaksanaan operasi SAR. Yang terakhir adalah pengawasan, pengawasan mencakup seluruh bagian-bagian manajemen logistik, pengawasan harus dilakukan dengan teliti dan objektif untuk mengontrol seluruh kegiatan manajemen logistik agar tercipta sebuah manajemen logistik yang benar-benar mampu menunjang pelaksanaan operasi pencarian dan pertolongan pada Kantor Search And Rescue (SAR) Kelas A Biak.

\section{DAFTAR PUSTAKA}

Ali, M. (2009). Pendidikan untuk pembangunan nasional: menuju bangsa Indonesia yang mandiri dan berdaya saing tinggi. Grasindo.

Anggarasena, B. (2010). Strategi Penegakan Hukum Dalam Rangka Meningkatkan Keselamatan Lalu Lintas Dan Mewujudkan Masyarakat Patuh Hukum. UNIVERSITAS DIPONEGORO.

Irmawati, L. I., \& PGDHS, A. S. M. (2015). Manajemen Logistik Farmasi: Buku Ajar: Pedoman Praktis S1 Administrasi Rumah Sakit. Institut Ilmu Kesehatan-University Press.

Iskandar, D. T., \& Erdelen, W. R. (2006). Conservation of amphibians and reptiles in Indonesia: issues and problems.

Karamy, S. (2015). Kewenangan negara terhadap penyelidikan kecelakaan penerbangan sipil internasional di laut lepas menurut hukum internasional (Studi Kasus Pesawat Malaysia Airlines MH370).

Katz, R. L. (2009). Skills of an effective administrator. Harvard Business Review Press.

Moleong, L. J. (2007). Metodologi Pendidikan Kualitatif. Bandung: Remaja Pustaka.

Munandar, H. (2008). Mengenal PMI dan BaSARnas, Dua Garda Terdepan Menghadapi Bencana: Misi, Peranan, serta Arti Penting PMI dan BaSARnas bagi masyarakat luas. Esensi.

Petrus, I. L. (2010). Analisis faktor-faktor makroekonomi yang mempengaruhi investasi sektor transportasi di Indonesia Periode 2001-2010. Sumber, 13787, 7.

Siagian, S. P. (1991). Kepemimpinan dan Perilaku Administrasi. Gunung Agung, Jakarta.

Siagian, S. P. (2003). Administrasi pembangunan: konsep, dimensi, dan strateginya. Bumi Aksara.

Sugiyono, D. (2006). Statistika untuk penelitian. Bandung: CV. Alfabeta.

Supriyono, S. (2010). Implementasi Traffic Accident Analysis Guna Menanggulangi Kecelakaan Lalu Lintas. UNIVERSITAS DIPONEGORO. 